\title{
Electrical Properties of RF Sputtered CdTe/CdS Thin Film Solar Cells
}

\author{
Sheeja Krishnan ${ }^{1}$, Ganesh Sanjeev ${ }^{2}$, Manjunatha Pattabi ${ }^{*}, 1$ and X. Mathew ${ }^{3}$ \\ ${ }^{1}$ Department of Materials Science, Mangalore University, Mangalagangotri-574 199, India \\ ${ }^{2}$ Microtron Centre, Department of Physics, Mangalore University, Mangalagangotri-574 199, India \\ ${ }^{3}$ Centro de Investigación en Energía, Universidad Nacional Autónoma de México, 62580, Temixco, Morelos, México
}

\begin{abstract}
The charge transport properties of $\mathrm{CdTe} / \mathrm{CdS}$ solar cells deposited by radio frequency (RF) sputtering have been investigated and presented in this article. The temperature dependent current-voltage characteristics of the devices under dark condition were carried out in the temperature range 240-340 K. The capacitance of the devices at various frequencies was also investigated.
\end{abstract}

Keywords: Cadmium telluride, solar cell, transport mechanism, current-voltage characteristics.

\section{INTRODUCTION}

Solar cells are the building blocks of photovoltaic systems. Solar cells are widely used in space program as power source for satellites as well as a major power source to meet earth's energy needs. Single crystalline Silicon and GaAs has been used extensively for space applications. Other schemes for power generation via solar cells include thin film solar cells [1] and multi-junction solar cells. Multijunction solar cells although more efficient have higher fabrication cost. Polycrystalline thin film CdTe solar cells are one of the important candidates for large scale photovoltaic applications because of their low cost, high efficiency and stable performance [2] and have been used for large area terrestrial applications [3]. Cadmium telluride is an important material for the development of low cost photovoltaic devices for space as well as terrestrial applications [2,4]. The properties of CdTe like an optimum band gap of $1.45 \mathrm{eV}$ and high optical absorption coefficient [5] makes it an important material for these applications.

An understanding of electrical properties of the solar cell is essential because the performance of the devices rely upon the conduction mechanisms. Most of the reported work on $\mathrm{CdTe} / \mathrm{CdS}$ solar cells is focused on opto-electronic properties. There are only a few studies on the electrical properties of $\mathrm{CdTe} / \mathrm{CdS}$ solar cells [6-8]. In this paper, the electrical characteristics of RF sputtered $\mathrm{CdTe} / \mathrm{CdS}$ solar cells have been investigated and the results are presented.

\section{EXPERIMENTAL}

$\mathrm{CdTe} / \mathrm{CdS}$ solar cells used in the present work were grown in a superstrate configuration, on Pilkington Tec 7 glass substrates. As the Pilkington Tec 7 glass is electrically conducting with a sheet resistance of 6-8 ohms/square and a transparency of $80-82 \%$, it is used as the lower electrode. The substrates were cleaned following the standard

*Address correspondence to this author at the Department of Materials Science, Mangalore University, Mangalagangotri- 574 199, India;

E-mail: manjupattabi@yahoo.com procedures and both CdTe and CdS films were deposited using RF sputtering technique. The thickness of the films was approximately $2.0 \mu \mathrm{m}$ for CdTe and $0.13 \mu \mathrm{m}$ for the $\mathrm{CdS}$ film. The $\mathrm{CdTe} / \mathrm{CdS}$ heterojunction was vapor chloride treated at $390{ }^{\circ} \mathrm{C}$ for 30 minutes under a flow of dry air. Pseudo ohmic contact to CdTe was obtained by vacuum evaporating $3 \mathrm{~nm}$ of $\mathrm{Cu}$ followed by $50 \mathrm{~nm}$ Au. The $\mathrm{Cu}$ diffusion was achieved by annealing the contacts at $150{ }^{\circ} \mathrm{C}$ for 35 minutes.

The areas of the solar cells were determined by the area of the $\mathrm{Cu} / \mathrm{Au}$ deposit and the area of the cell used in the present study is $0.122 \mathrm{~cm}^{2}$. I-V characteristics of the solar cells under dark were measured using a Lab Equip DLS2000 system. Capacitance measurements of the devices at various frequencies were made under dark condition using a Keithley 3322 LCZ meter.

\section{RESULTS AND DISCUSSION}

Current-voltage (I-V) characteristics of the solar cells were investigated in the $240-340 \mathrm{~K}$ range to identify the dominant charge transport mechanism in the region. Fig. (1) shows the I-V characteristics of the solar cells at various temperatures.

The forward I-V characteristics can be expressed using the diode equation [9].

$$
I=I_{0} \exp \left(\frac{q V}{n k T}\right)
$$

where $\mathrm{n}$ is the diode ideality factor, $\mathrm{I}_{0}$ is the reverse saturation current and $\mathrm{k}$ is the Boltzmann constant.

with

$$
I_{0}=I_{00} \exp \left(\frac{-\Delta E}{k T}\right)
$$

where $\Delta \mathrm{E}$ is the thermal activation energy of the process.

In order to identify the current transport mechanism through the junction, $\mathrm{I}_{0}$ was plotted as a function of $1000 / \mathrm{T}$ as shown in Fig. (2). 


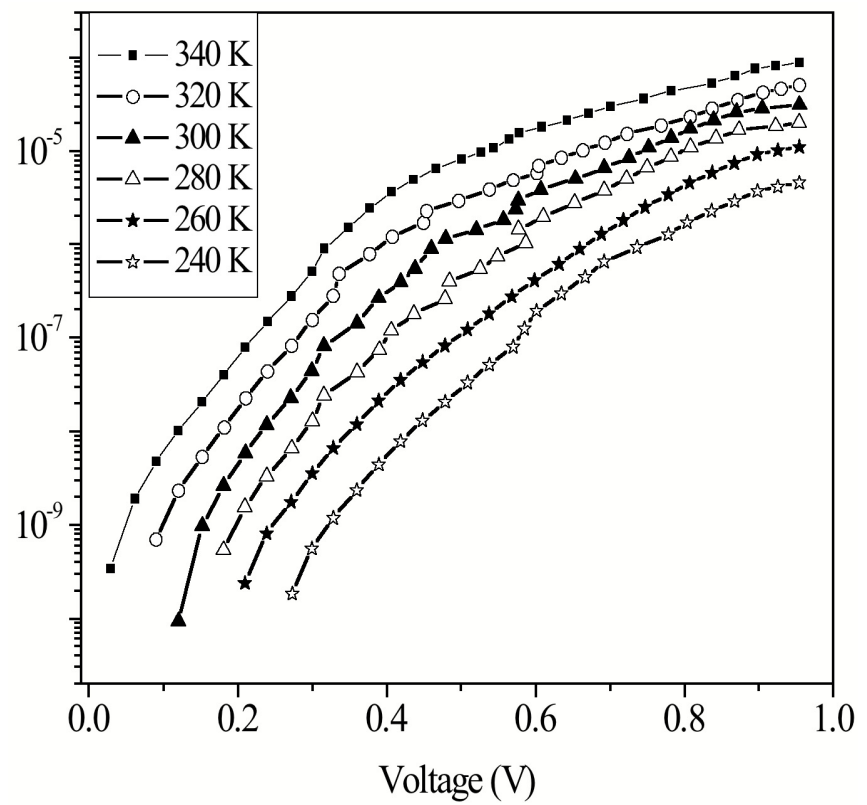

Fig. (1). I-V characteristics of $\mathrm{CdTe} / \mathrm{CdS}$ solar cells at different temperatures on a semilogarithmic scale.

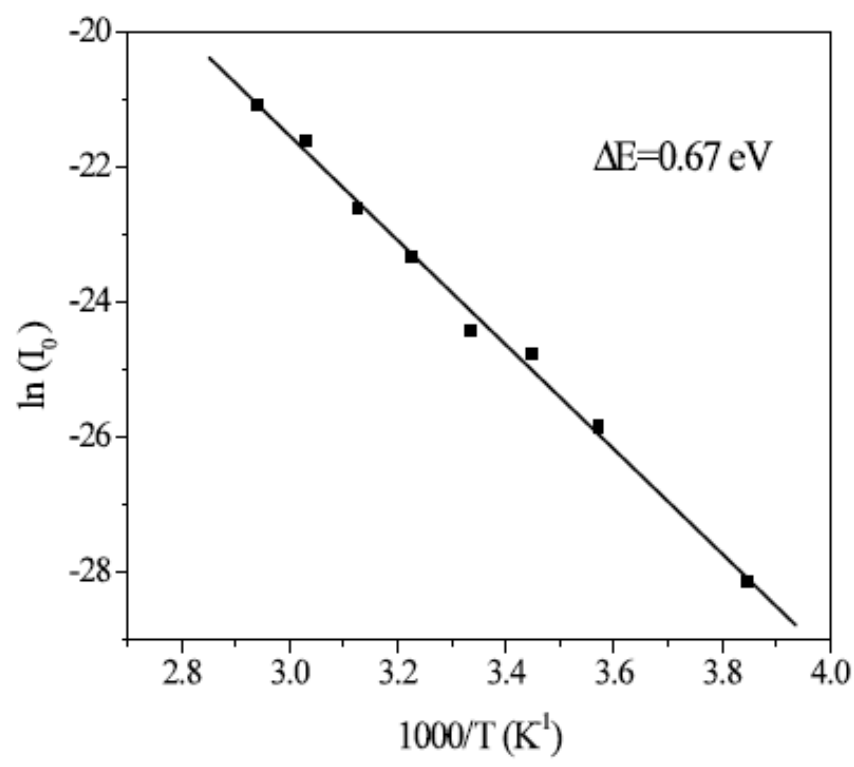

Fig. (2). $\mathrm{Ln} \mathrm{I}_{0}$ vs 1000/T for the CdTe/CdS solar cell.

The variation of $\ln \mathrm{I}_{0}$ vs $1000 / \mathrm{T}$ is found to be linear, indicating the presence of a single transport mechanism. The activation energy calculated from the plot is $0.67 \mathrm{eV}$.

For interface recombination dominated current transport, the value of $n$ should be approximately equal to 1 . Since the carrier density in CdS is much larger than that of CdTe, the activation energy of the $\ln \left(\mathrm{I}_{0}\right)$ vs $1000 / \mathrm{T}$ plot should be equal to the built-in voltage of the $\mathrm{CdS} / \mathrm{CdTe}$ hererojunction $(1.18 \mathrm{eV})[10]$. In this case the value of the ideality factor calculated from the $\ln (\mathrm{I}) v s \mathrm{~V}$ plot is 1.58 and the plot (Fig. 2) gives an activation energy of $0.67 \mathrm{eV}$. This indicates that interface recombination is not the dominant mechanism of current transport.
If recombination through localized states within the CdTe depletion region is dominant, then a plot of $\ln \left(\mathrm{I}_{0} \mathrm{~T}^{-2.5}\right) \mathrm{vs}$ $1000 / \mathrm{T}$ should yield an activation energy approximately equal to half of the CdTe band gap $[11,12]$.

Fig. (3) shows the plot of $\ln \left(\mathrm{I}_{0} \mathrm{~T}^{-2.5}\right)$ as a function of inverse temperature. The activation energy calculated from the plot is $0.59 \mathrm{eV}$, which lies too far from half the CdTe band gap. So the validity of depletion region recombination also seems to be doubtful.

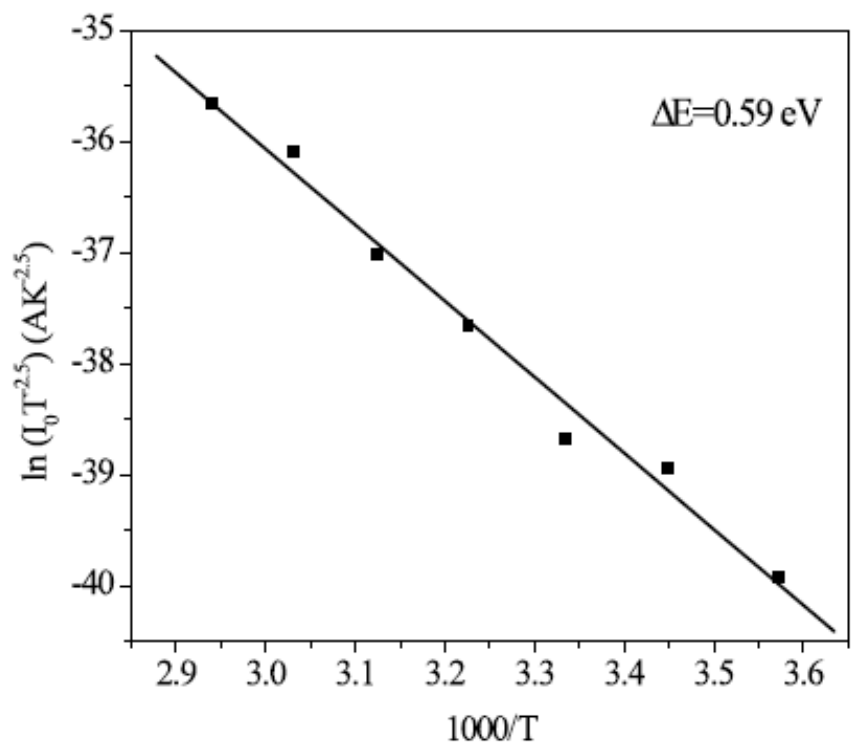

Fig. (3). Plot of $\ln \left(\mathrm{I}_{0} \mathrm{~T}^{-2.5}\right)$ versus $1000 / \mathrm{T}$ for the $\mathrm{CdTe} / \mathrm{CdS}$ solar cell.

The variation of ideality factor calculated from the $\ln (\mathrm{I})$ $v s \mathrm{~V}$ plot with temperature is not very significant. All these indicate that thermally assisted tunneling $[13,14]$ could be the dominant current transport mechanism in $\mathrm{CdTe} / \mathrm{CdS}$ solar cells. However, more work is required in order to explain the tunneling mechanism in these devices.

I-V characteristics of the devices were also measured under illumination condition and the values of $\mathrm{FF}, \mathrm{I}_{\mathrm{sc}}, \mathrm{V}_{\mathrm{oc}}$ and efficiency calculated from the measurements are 0.405 , $1.47 \mathrm{~mA}, 0.76 \mathrm{~V}$ and $6.25 \%$ respectively.

Fig. (4) shows the variation of capacitance with frequency at 1 Volt for the $\mathrm{CdTe} / \mathrm{CdS}$ solar cells measured under dark condition. As the frequency increases, the capacitance was found to decrease for the CdTe solar cell. The decrease in capacitance with frequency indicates the existence of deep levels at or near the $\mathrm{CdTe} / \mathrm{CdS}$ interface [12].

Variation of the interface state capacitance, $\mathrm{C}_{\mathrm{ss}}$ with frequency is given by $[15,16]$.

$C_{s s}=\frac{A q N_{s s}}{\tau} \frac{\arctan (\omega \tau)}{\omega}$

where $N_{s s}$ is the density of interface states, $A$ is the area, $\omega$ is the frequency and $\tau$ is the relaxation time of the interface state. 


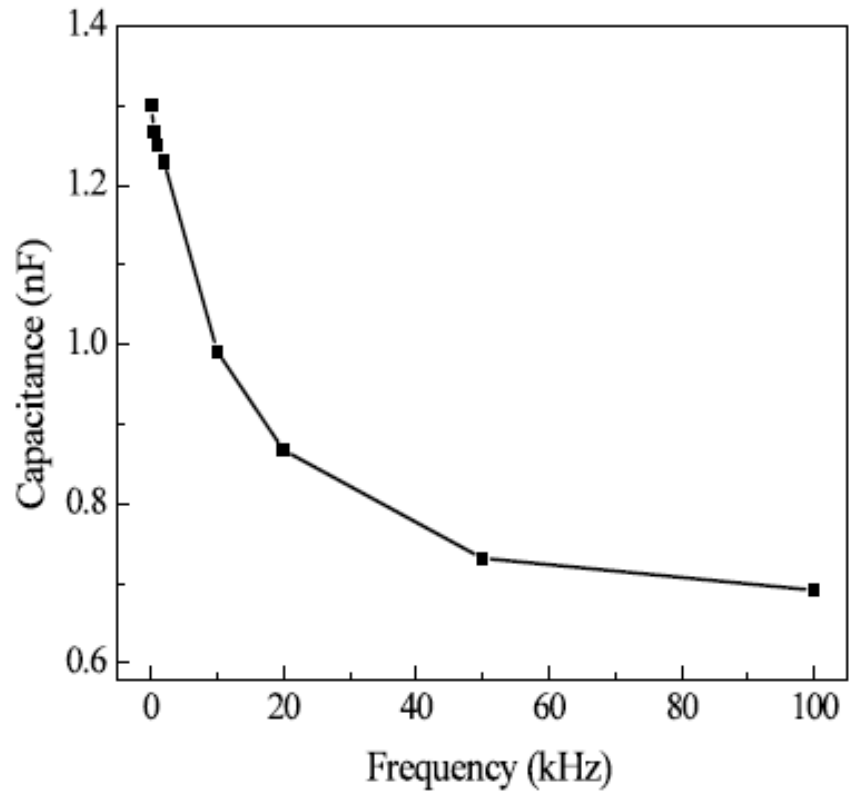

Fig. (4). Variation of capacitance with frequency at 1 Volt for a $\mathrm{CdTe} / \mathrm{CdS}$ solar cell.

The interface state density obtained from the C-f plot was $9.86 \times 10^{10} \mathrm{eV}^{-1} \mathrm{~cm}^{-2}$.

\section{CONCLUSION}

The current transport properties of $\mathrm{CdS} / \mathrm{CdTe}$ heterojunction solar cells under dark condition in the temperature range 240-340 $\mathrm{K}$ were investigated. The transport mechanism of the solar cells appeared to be thermally assisted tunneling in the forward bias region. Capacitance-frequency measurements indicated the presence of deep levels at or near the CdTe/CdS interface.

\section{ACKNOWLEDGEMENT}

The authors thank Prof. G. K. Shiva Kumar, NITK, for extending facilities for capacitance measurements. One of the authors (SK) gratefully acknowledges BRNS, Department of Atomic Energy, Govt. of India, for financial assistance. The authors thank the technical staff of Microtron Centre for their help.

\section{REFERENCES}

[1] Hovel, H. J. Semiconductors and Semimetals Solar cells, Academic press: Newyork, 1975, Vol 2, p. 3

[2] Niemegeers, A.; Burgelman, M. Effects of the $\mathrm{Au} / \mathrm{CdTe}$ back contact on the IV and CV characteristics of $\mathrm{Au} / \mathrm{CdTe} / \mathrm{CdSe} / \mathrm{TCO}$ solar cells. J. Appl. Phys., 1997, 81, 2881-2286.

[3] Wimbor, M.; Romeo, A.; Igalson, M. Electrical Characterization of $\mathrm{CdTe} / \mathrm{CdS}$ photovoltaic devices. Opto-Electron. Rev., 2000, 8(4), 375-377.

[4] Ferekides, C.; Britt, J.; Ma, Y.; Kilian, L. High Efficiency CdTe Solar Cells by Close Spaced Sublimation. Proceedings of 23rd IEEE Photovoltaic Specialist Conference, Louisville, KY, May 1014,1993 , pp. 389-393.

[5] Lofersky, J.J.; Theoretical considerations governing the choice of the optimum semiconductor for photovoltaic solar energy conversion. J. Appl. Phys., 1956, 27, 777-785.

[6] Mancini, A.M.; Quirini, A.; Rizzo, A.; Vasanelli, L; Paorici, C. Electrical properties of $\mathrm{CdTe} / \mathrm{CdS}$ heterojunctions obtained by closed-tube chemical transport. Phys. Status Solid (a), 2006, 57, 783-788.

[7] Niemegeers, A.; Burgelman, M. Effects of the Au/CdTe back contact on $I V$ and $C V$ characteristics of $\mathrm{Au} / \mathrm{CdTe} / \mathrm{CdS} / \mathrm{TCO}$ solar cells. J. Appl. Phys., 1997, 81, 2881-2885.

[8] Friesen, G.; Dunlop, E.D.; Wendt, R. Investigation of CdTe solar cells via capacitance and impedence measurements. Thin solid Films, 2001, 387, 239-242.

[9] Sze, S.M.; Physics of Semiconductor Devices, $2^{\text {nd }}$ ed.; Wiley Interscience: New York, 1981, p. 81.

[10] Mitchell, K.W.; Fahrenbruch, A.L.; Bube, R. H. Evaluation of the CdS/CdTe heterojuntion solar cells. J. Appl. Phys., 1977, 48, 43654372.

[11] Ringel, S.A.; Smith, A.W.; MacDougal, M. H.; Rohatgi, A. The effects of $\mathrm{CdCl}_{2}$ on the electronic properties of molecular-beam epitaxially grown $\mathrm{CdTe} / \mathrm{CdS}$ heterojunction solar cells. J. Appl. Phys., 1991, 70, 881-890.

[12] Yoo, J. B.; Fabrenbruch, A. L.; Bube, H. Transport mechanisms in $\mathrm{ZnO} / \mathrm{CdS} / \mathrm{CuInSe}{ }_{2}$ solar cells. J. Appl. Phys. 1990, 68, 4694-4700.

[13] Anderson, W. W.; Hoffman, H. J. Filed Ionization of deep levels in semiconductors to $\mathrm{Hg}_{1-\mathrm{x}} \mathrm{Cd}_{\mathrm{x}} \mathrm{Te}$ p-n junctions. J. Appl. Phys. 1982, 53, 9130-9146.

[14] Blanks, D. K.; Beck, J. D.; Kinch, M. A.; Colombo, L. Band-toband tunnel processes in $\mathrm{HgCdTe}$ : comparison of experimental and theoretical studies. J. Vac. Sci. Technol., 1988, A6, 2790-2794.

[15] Singh, A. Characterization of interface states at $\mathrm{Ni} / \mathrm{nCdF}_{2}$ Schottky barrier type diodes and the effect of $\mathrm{CdF}_{2}$ surface preparation. Solid State Electron., 1985, 28, 223-232.

[16] Ayyildiz, E.; Nuho, L.C.; Turut, A. The determination of the interface-state density distribution from the capacitance-frequency measurements in $\mathrm{Au} / \mathrm{n}-\mathrm{Si}$ schottky barrier diodes, J. Electron Mater., 2002, 31, 119-123. 